\title{
THE EFFECT OF SALICYLATES AND ADRENOCORTICOTROPIC HORMONE UPON THE MISCIBLE POOL OF URIC ACID IN GOUT ${ }^{1}$
}

\author{
By JEAN D. BENEDICT, PETER H. FORSHAM, MARCEL ROCHE, SIDNEY \\ SOLOWAY, AND DEWITT STETTEN, JR.
}

\author{
(From the Division of Nutrition and Physiology, the Public Health Research Institute of the \\ City of New York, Inc., New York; and the Medical Clinic, Peter Bent Brigham \\ Hospital and the Department of Medicine, Harvard Medical School, Boston)
}

(Submitted for publication May 15, 1950; accepted, May 22, 1950)

In a previous report (1) were described the results of experiments in which isotopic uric acid was injected intravenously into normal and gouty human male subjects. The purpose was to ascertain the magnitude of the "miscible pool," that quantity of uric acid present in the body capable of prompt mixing with the injected material, and the rate of its turnover. The results indicated that there are some $1200 \mathrm{mg}$. of miscible uric acid normally present, a finding in accord with that of Geren and associates (2), that between 50 and $75 \%$ of this is each day replaced by newly formed uric acid and that this latter quantity exceeds the quantity excreted daily in the urine, suggesting the occurrence of limited catabolism of uric acid in man. In the gouty subjects studied, the magnitude of this miscible pool exceeded the normal levels by as much as 15 fold. Indeed, so large was the quantity of promptly miscible uric acid as to indicate that at least a portion of this material must reside in the solid phase rather than in solution in body fluids.

In the present study ${ }^{2}$ we have extended our observations on the amount and distribution of miscible uric acid in the gouty patient and have investigated the effects upon these quantities of some of the therapeutic agents commonly employed in this disease. The effect of $\mathrm{ACTH}^{3}$ on the normal subject has also been studied.

\section{MATERIALS AND METHODS}

The preparation of isotopic uric acid labeled in the one and three positions with $\mathrm{N}^{15}$, the isolation of uric acid

1 This study was aided in part by grants from the Division of Endocrinology, the United States Public Health Service, and Armour and Co.

2 A preliminary report of this work has appeared (3).

${ }^{3} \mathrm{We}$ are indebted to Dr. John R. Mote, Medical Director, the Armour Laboratories, Chicago, for the ACTH used in these studies. from the urine samples and isotope analysis have all previously been described (1). The only novel chemical procedure was the analysis of a tophus excised from subject A. L. on the ninth day of his third experiment. This specimen when dried in vacuo over $\mathrm{P}_{2} \mathrm{O}_{5}$ weighed $6.8 \mathrm{gm}$. In the expectation of dissolving successive laminae of uric acid, the tophus was then placed in the thimble of a Soxhlet apparatus over boiling water and extracted for three periods of 24 hours each, the contents of the flask being replaced by fresh water after each period. An aliquot of each extract was analyzed for uric acid by the method of Forsham and co-workers (4) and pure uric acid was isolated from the remaining extract for isotope analysis by the same method previously employed in the isolation from urine (1). The residue of the tophus was boiled in $500 \mathrm{ml}$. of $0.07 M \mathrm{Li}_{2} \mathrm{CO}_{3}$ for one hour, the solution filtered, and analyzed for uric acid. The same mathematical treatment of results has been employed as was described in the earlier report (1).

Both the normal and gouty subjects were maintained in slightly positive nitrogen balance on constant diets calculated to contain purines equivalent to 2.4 to $3.1 \mathrm{mg}$. of uric acid per day. It was found that a preliminary period of at least three days on this diet was required to achieve a reasonably constant urinary uric acid output. Sterile solutions of the lithium salt of isotopic uric acid were prepared and injected intravenously as previously described (1). The injection was carried out over a period of 30 minutes and the midpoint was taken as zero time in the subsequent calculations.

The total urine output of each subject was collected in 12 hour portions, and each sample was analyzed for uric acid by the method of Forsham and colleagues (4). From 94 to $98 \%$ of the chromogenic material in urine determined by the method was found to be destroyed by uricase. Pending isolation of urinary uric acid for isotopic determination, the samples were preserved by freezing.

\section{Subjects}

W. A. was a normal 22 year old male medical student with no familial history of gout. He was placed on a constant purine-low diet prior to the intravenous injection of isotopic uric acid. On the second and third day following this infusion $25 \mathrm{mg}$. of ACTH were administered intramuscularly every six hours to a total of $200 \mathrm{mg}$. 

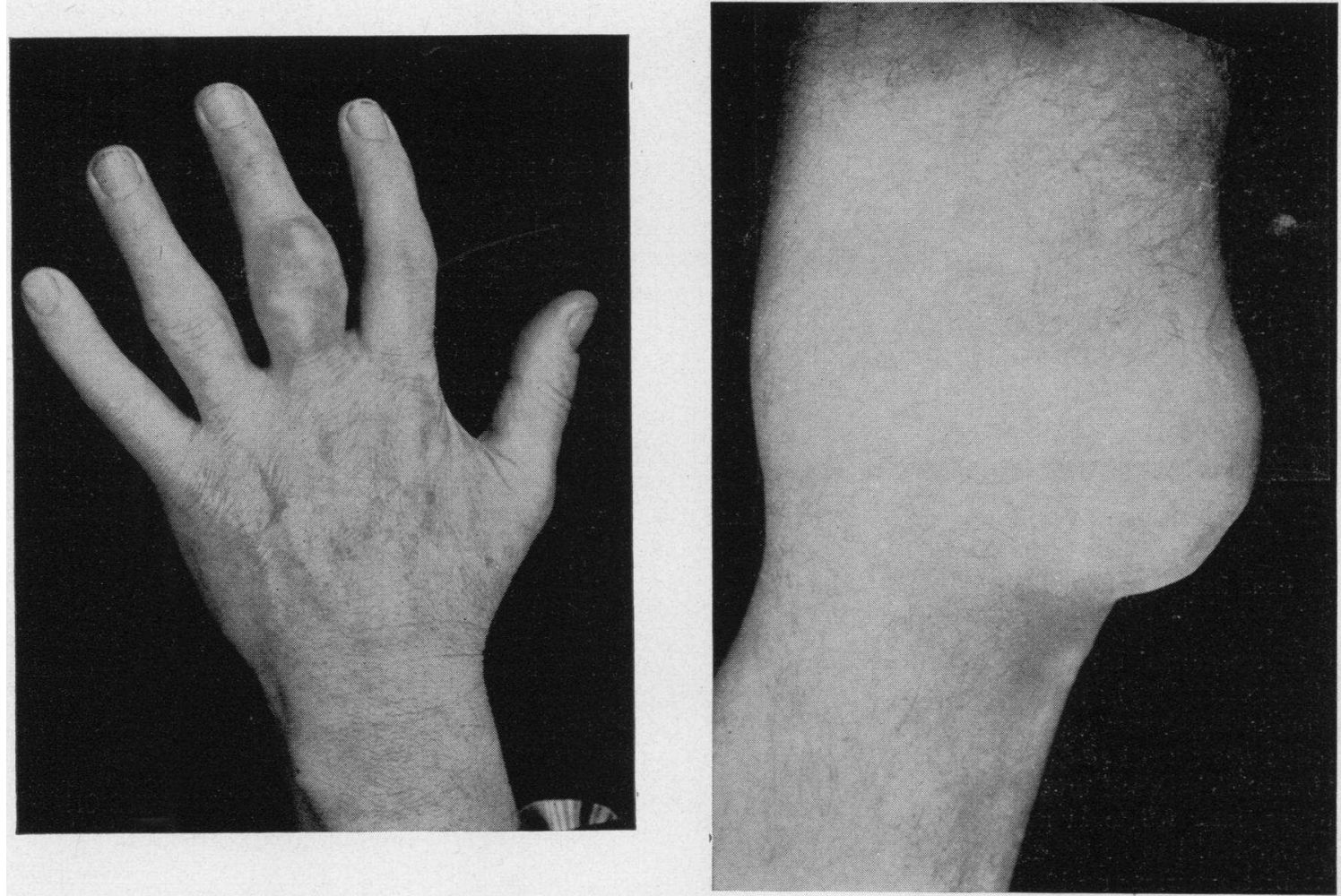

Fig. 1. A. L. Left Hand and Left KneE

Note the large tophaceous deposits in the proximal portion of the middle finger and over the patella.

A. L., a 64 year old former hotel manager of North Italian extraction who was suffering from severe chronic tophaceous gout, had previously been studied by this technique (1). He was subjected to two further investigations; first, after a period of scant and irregular medication, then again after a protracted course of salicylates. The possible effect of ACTH was explored during the former of these two experiments, that of colchicine during the latter.

First admission-In 1924 (age 39), the patient broke two right metatarsal bones. Seven days after the application of a plaster cast, the patient experienced an acutely red and painful swollen right wrist and returned to the hospital for treatment. The pain continued for several weeks. Because of the possibility that the inflammation of the wrist may have been due to secondary infection, the patient's tonsils were removed. The pain slowly subsided after this. No determinations of uric acid were done.

From 1924 to 1937 the patient enjoyed excellent health, living on a very rich diet with frequent partaking of anchovies, caviar, sweetbreads, foie gras and a moderate intake of alcohol, all incidental to his occupation.

In the winter of 1937 he experienced his second attack of joint pain, accompanied by swelling and redness, this time of the right knee. A diagnosis of gout was made at an outside hospital. The patient was placed on a low purine diet which he has followed ever since.
From 1937 to 1940 there were many and frequent attacks of arthralgia, each one lasting for from one to two weeks. Deposits began to develop around the joints and by 1940 motion of practically all the joints of the extremities was severely limited.

From 1940 on the pain was only rarely acute, but there was constant joint ache and impaired mobility; the patient was reduced to a state of chronic invalidism.

Approximately five months before his second admission he was again seen at an outside hospital where he was placed on a regimen of aspirin $4.8 \mathrm{gm}$. to be taken every third to fourth day.

Outside of the history of high purine intake, there was nothing of significance in the patient's past history. There was no familial background of gout or any other joint disease.

Second admission, Feb. 4, 1949-Physical examination revealed a well nourished (wt. $75 \mathrm{~kg}$.) alert and pleasant man. Firm subcutaneous deposits could be plainly seen and felt around both first metatarso-phalangeal joints, over the patellae and around several of the finger joints (Figure 1). Over the olecranon areas, on both sides, there were well healed scars at the sites where large tophaceous deposits had been excised at another hospital. A toe removed at this admission showed a massive tophus (Figure 2).

$\mathrm{X}$-ray studies showed many areas of cystic destruction of the bones characteristic of gout. Blood and urine 


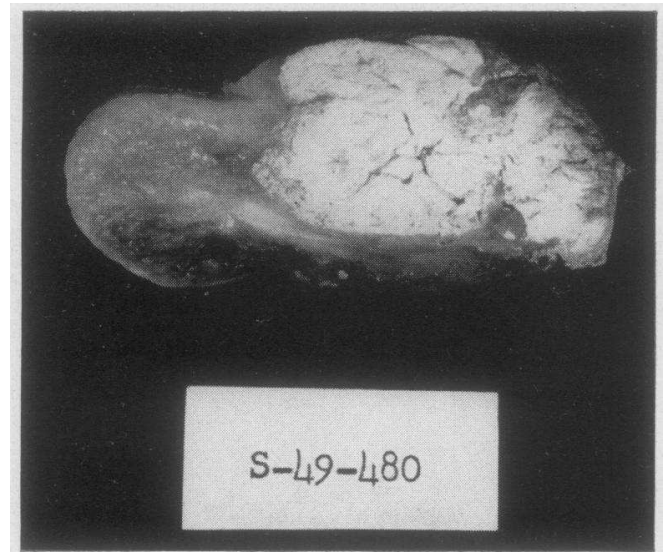

Fig. 2. A. L. Cross Section of the Patient's Left First Metatarsal

The bone has been destroyed by a large tophus.

studies were normal except for a slight normocytic anemia (hematocrit $38 \%$ ) and a serum uric acid of $10 \mathrm{mg} . \%$. Maximum urea clearance was $135 \%$ of normal and PSP excretion was normal at $32 \%$ in 15 minutes and $70 \%$ in two hours. The blood urea nitrogen was $19 \mathrm{mg}$. \% on admission, later fell to $11 \mathrm{mg}$. $\%$ on two occasions. It was never found to be elevated during later admissions.

The first experiment with isotopic uric acid was carried out during this admission with the patient on a purine-low diet. Thereafter the patient received a six day course of ACTH (40 mg./day) with good clinical improvement associated with a transitory increase in uric acid excretion (Figure 3) and a fall in serum uric acid from 10.1 to $5.3 \mathrm{mg}$. \%.

The patient was discharged on a purine-low diet and was told to take aspirin and colchicine as needed. This he did only infrequently, since he had a feeling that they helped him very little (Table I).

TABLE I

Summary of treatment of $A$. L.

\begin{tabular}{|c|c|c|}
\hline Date & Period & Daily medication \\
\hline $10 / 10 / 48-2 / 10 / 49$ & Before first study & $\begin{array}{l}\text { Aspirin } 4.8 \mathrm{gm} \text {. every } \\
\text { four days }\end{array}$ \\
\hline $2 / 10 / 49-2 / 17 / 49$ & First is tope study & \\
\hline $\begin{array}{l}2 / 17 / 49-2 / 23 / 49 \\
2 / 23 / 49-5 / 27 / 49 \\
5 / 27 / 49-6 / 21 / 49 \\
\end{array}$ & Interim & $\begin{array}{l}\text { ACTH } 40 \mathrm{mg} \text {. } \\
\text { Aspirin and colchicine } \\
\text { irregularly } \\
\text { No treatment }\end{array}$ \\
\hline $\begin{array}{l}6 / 21 / 49-6 / 28 / 49 \\
6 / 23 / 49 \\
6 / 24 / 49\end{array}$ & Second isotope study & $\begin{array}{l}\text { ACTH } 80 \mathrm{mg} . \\
\text { ACTH } 80 \mathrm{mg} .\end{array}$ \\
\hline $\begin{array}{l}6 / 28 / 49-7 / 5 / 49 \\
7 / 5 / 49-8 / 23 / 49 \\
8 / 23 / 49-9 / 20 / 49 \\
9 / 20 / 49-11 / 1 / 49\end{array}$ & Interim & $\begin{array}{l}\text { ACTH } 30 \mathrm{mg} . \\
\text { Aspirin } 3.6 \mathrm{gm} . \\
\text { Aspirin } 2.4 \mathrm{gm} . \\
\text { Aspirin } 2.7 \mathrm{gm} .\end{array}$ \\
\hline $\begin{array}{l}11 / 1 / 49-11 / 6 / 49 \\
11 / 3 / 49 \\
11 / 4 / 49 \\
11 / 9 / 49\end{array}$ & Third isotope study & $\begin{array}{l}\text { Colchicine } 4.8 \mathrm{mg} \text {. } \\
\text { Colchicine } 4.8 \mathrm{mg} \text {. } \\
\text { Tophus removed from } \\
\text { ankle }\end{array}$ \\
\hline
\end{tabular}

Third admission, May 24, 1949-The patient was admitted for a few days for a study on an artificial kidney. During this study he received $80 \mathrm{mg}$. of ACTH.

Two or three days after discharge, the patient experienced one of his rare acute gouty attacks involving the right first metatarsal joint and leading to a discharge of gouty matter through a break in the skin resulting in secondary infection which was treated conservatively.

One month prior to his fourth admission the patient stopped all salicylate and colchicine medication (Table I).

Fourth admission, June 15, 1949-The patient was treated with penicillin alone soon after admission. The second isotopic uric acid study was performed during this admission. ACTH was given intramuscularly on the second and third days following the infusion of isotopic uric acid, $80 \mathrm{mg}$./day in four divided doses. The patient was discharged on July 19, 1949 and was instructed to take $3.6 \mathrm{gm}$. of acetylsalicylate daily at home. This dose had to be reduced to $2.4 \mathrm{gm}$. daily as the patient developed some epigastric pains and experienced two episodes of melena because of the reactivation of an old duodenal ulcer.

Fifth admission, October 24, 1949-After a six day pe-

\section{EFFECT OF VARIOUS DRUGS ON URIC ACID EXCRETION}

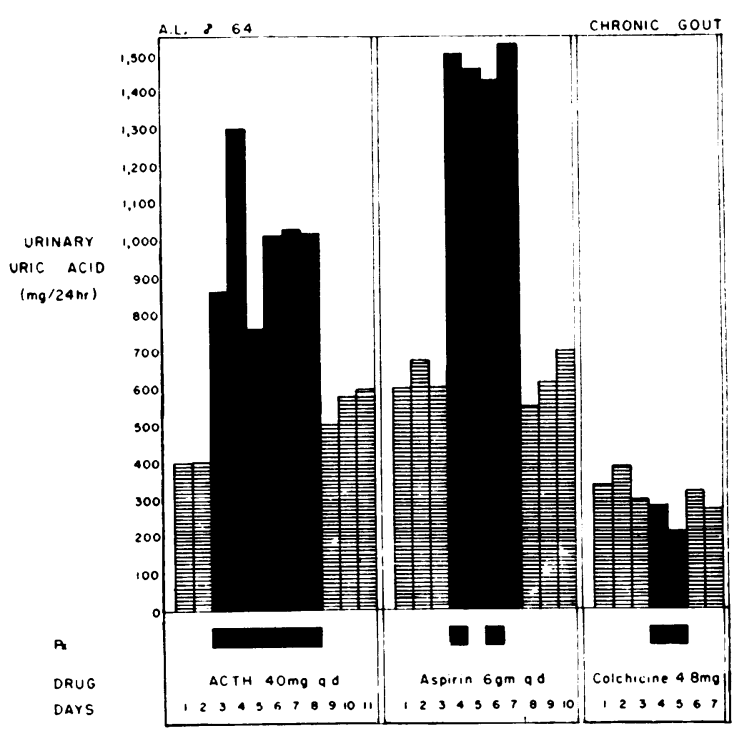

Fig. 3. A. L. Urinary Uric Acid Excretion

The experiments with $\mathrm{ACTH}$ and with acetylsalicylic acid were carried out on the first admission. Full oral doses of salicylate produced a prompt maximal rise of urinary uric acid which lasted for 24 hours after discontinuing the drug. ACTH produced a smaller, more gradual rise, with a prompt return to basal levels after stopping the administration. The experiment with colchicine was performed seven months after the first two experiments, at a time when the "miscible pool" had been markedly reduced. 


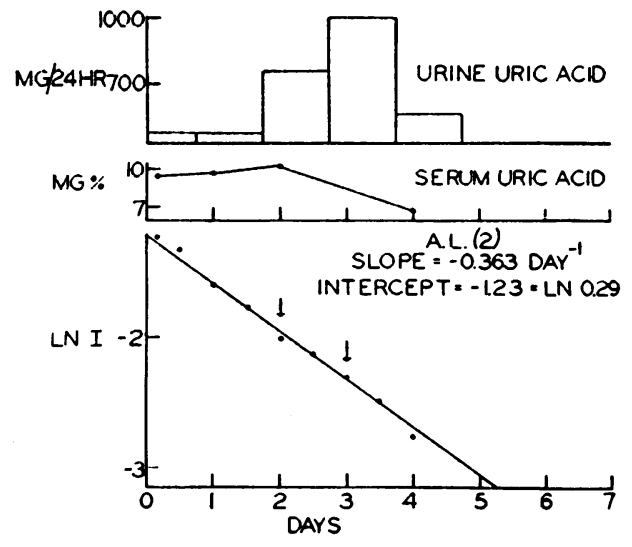

Fig. 4. A. L.-2. Measurement of the Miscible Pool of Uric Acid after a Period Without Treatment

$80 \mathrm{mg}$. of ACTH were administered on days 2 and 3.

riod without medication the third isotopic uric acid study was carried out. During this experiment colchicine, 4.8 mg./day in four divided doses, was given on the second and third days after the intravenous administration of labeled uric acid. The patient developed no signs of colchicine overdosage on this regimen. Nine days following the start of this experiment a large tophus over the left ankle was removed surgically for isotopic study.

There were no obvious clinical differences noted at the times of the three isotope experiments. The tophi appeared no different in size or consistency. A distinct softening of the tophi was observed each time the patient was given ACTH but there was no reduction in size. No untoward effect was observed during the administration of intravenous uric acid, except on the third occasion when, shortly after the beginning of the infusion, the patient developed nausea, vomited once and soon thereafter developed a generalized urticarial rash. The injection was continued, the patient was given $100 \mathrm{mg}$. of pyribenzamine immediately and all symptoms of this "tubing reaction" disappeared within half an hour.

\section{RESULTS}

The results of the first experiment on gouty subject A. L. have previously been reported (1). In
Figures 4 and 5 are recorded the analytical values obtained in the second and third studies of this patient. As in the earlier report, the concentrations of isotope in urinary uric acid (I) have been plotted against time (days) on semilogarithmic coordinates because it was shown that under these circumstances, a straight line would be obtained whose slope $(-K)$ was numerically equal to the fraction of the pool replaced per day by new uric acid. The intercept $\left(\ln \mathrm{I}_{0}\right)$ is then the natural logarithm of the isotope concentration of the miscible uric acid at the moment of mixing. From this quantity, together with the quantity and isotope concentration of the uric acid injected, the magnitude of the miscible pool has been computed.

In Table II are given the summaries of the results of three experiments conducted on this subject. The miscible pool contained about 18,000 mg. of uric acid at the time of the first experiment. During the four and one-half months intervening between the first and second experiments, the pa-

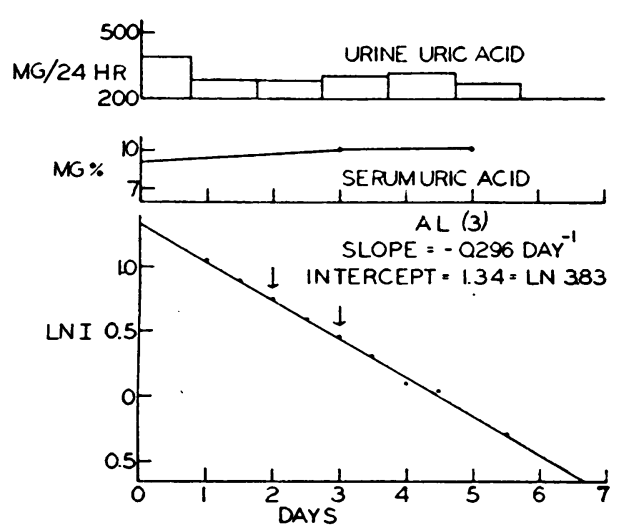

Fig. 5. A. L.-3. Measurement of the Miscible Pool of Uric Acid after Prolonged Treatment With Salicylates

Colchicine $4.8 \mathrm{mg}$. q. d. was administered on days 2 and 3.

TABLE II

Injection of isotopic uric acid into gouty patient A. L.*

\begin{tabular}{|c|c|c|c|c|c|c|c|c|c|}
\hline $\begin{array}{c}\text { Experi- } \\
\text { ment }\end{array}$ & $\begin{array}{l}a=\text { dose } \\
\text { injected }\end{array}$ & $I_{i}=$ injected & $\begin{array}{c}\mathbf{I}_{0}=\text { antiln of } \\
\text { intercept }\end{array}$ & $\underset{\text { pool }}{A=\text { miscible }}$ & $\mathrm{K}=$-slope & $\underset{\text { turnover }}{\mathrm{KA}=}$ & $\begin{array}{c}\mathrm{C}=\text { body } \\
\text { weight }\end{array}$ & $\begin{array}{c}\mathrm{A} / 0.7 \mathrm{C}=\text { mean } \\
\text { conc. in body } \\
\text { water }\end{array}$ & $\begin{array}{c}\text { Mean serum } \\
\text { level }\end{array}$ \\
\hline $\begin{array}{l}1 \\
2 \\
3\end{array}$ & $\begin{array}{c}m g . \\
75.0 \\
306 \\
300\end{array}$ & $\begin{array}{l}\text { at. } \% \\
29.6 \\
29.6 \\
30.4\end{array}$ & $\begin{array}{l}\text { at. } \% \\
0.12 \\
0.29 \\
3.83\end{array}$ & $\begin{array}{r}m g . \\
18,450 \\
31,019 \\
2,081\end{array}$ & $\begin{array}{c}d a y^{-1} \\
0.463 \\
0.363 \\
0.296\end{array}$ & $\begin{array}{r}m g . / \text { day } \\
8,542 \\
11,260 \\
616\end{array}$ & $\begin{array}{l}\text { kg. } \\
75 \\
75 \\
75\end{array}$ & $\begin{array}{c}m g . \% \\
35.1 \\
59.1 \\
4.0\end{array}$ & $\begin{array}{c}m g . \% \\
9.6 \pm .1 \\
9.5 \pm .1 \\
10.2 \pm .1\end{array}$ \\
\hline
\end{tabular}

* The size of the miscible pool of uric acid in this subject has been determined on three occasions by the measurement of the dilution of isotope which results when isotopic uric acid is injected intravenously. 
tient received medication inconstantly and during the last month of this period no medication was taken (Table I). At the time of the second experiment, the miscible pool had increased to a value of $31,000 \mathrm{mg}$., almost twice the earlier value or approximately 30 times normal. It is noteworthy that this increase was not accompanied by any significant change in the serum uric acid concentration (last column, Table II). The figures in the next to the last column represent the mean concentrations of uric acid throughout total body water calculated on the assumptions that all the uric acid in the pool is uniformly distributed throughout all the water of the body $(0.7 \times$ body weight $)$. In the normal subjects, such a calculation gave values of approximately half the serum uric acid concentrations. In the untreated gouty subject, this value is far above the serum level, in the present instance far above the expected solubility of uric acid in saturated physiological solution. In the normal subject it was concluded that miscible uric acid is present in some body fluids in concentrations far lower than in plasma, whereas in the gouty subject a large reservoir of miscible uric acid must be postulated, and in view of its size and the relative insolubility of uric acid in physiological solutions, the bulk of this reservoir would appear to be in the solid phase.

During the three months which intervened between the second and third experiments, the patient received aspirin, 2.6-4.0 gm. daily, and although continuous analytical data are not available, spot-checking revealed a urinary excretion of uric acid of approximately $300 \mathrm{mg}$./day over this subject's basal excretory level. At the time of the third experiment, his miscible pool of uric acid had contracted to about $2000 \mathrm{mg}$., about onefifteenth of its previous value and about twice the normal value. This dramatic response to therapy was not accompanied by any significant fall in the serum uric acid concentration. It should be noted that there was no clinically obvious diminution in the mass of palpable and visible tophi during this interval. As a consequence of this contracture of the miscible pool, when the mean distribution of miscible uric acid throughout body water was computed, a concentration lower than that in the serum was found just as in the normal subjects.

On the ninth day of the same experiment, a
TABLE III

The concentrations of $N^{15}$ in serial extracts of a tophus*

\begin{tabular}{c|c|c}
\hline \hline Extract & Uric acid & $\mathrm{N}^{15}$ \\
\hline No. & $m g$. & atom \% \\
1 & 240 & 0.019 \\
2 & 705 & 0.014 \\
3 & 465 & 0.006 \\
Residue & 540 & 0.005 \\
Total & 1950 & \\
\hline
\end{tabular}

* The tophus was excised on the ninth day of experiment A.L.-3. Its dry weight was $6.82 \mathrm{gm}$. The pool of uric acid at that time contained 0.27 atom $\% \mathrm{~N}^{15}$.

tophus was excised from the patient's ankle. At this time the uric acid in the miscible pool had an isotope concentration (extrapolated) of 0.27 atom $\%$ excess $\mathrm{N}^{15}$. By serial extraction of this specimen, successive laminae of uric acid apparently were removed, as is indicated by the progressive decrease in isotope abundance of the uric acid extracted (Table III). The isotope concentration even in the first extract was notably low, about one-fourteenth that in the miscible pool, indicating that at this time very little of the solid phase urate was in equilibrium with uric acid in the miscible pool.

The administration of ACTH to subject A. L. during his second experiment resulted in a satisfactory adrenal cortical activation as shown by a fall of circulating eosinophils from 1213 to 58/ cu. $\mathrm{mm}$. in 48 hours and a uric acid diuresis of some $300 \mathrm{mg}$./day above basal values (Figure 4). This urinary loss of uric acid was accompanied by an appreciable decline in the serum uric acid
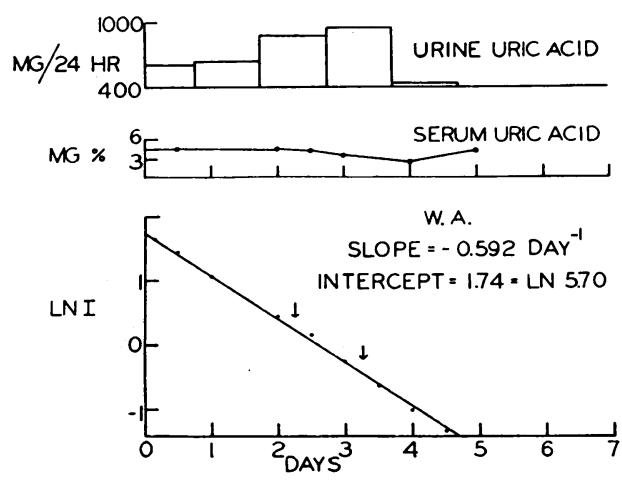

Fig. 6. W. A. Measurement of the Miscible Pool of Uric Acid in a Normal Subject

$100 \mathrm{mg}$. of ACTH were administered on days 2 and 3. 
from 10.2 to $6.7 \mathrm{mg}$. \%. Had the increase in urinary uric acid resulted from an increase in uric acid production this decline in serum level would not have been expected to occur and an increase in the rate of fall of isotope concentration in urinary uric acid would have been anticioated.

In order to obviate any possible masking of the effect of ACTH upon the pool of miscible uric acid incident to the enormous size of the pool in this patient, it was decided to repeat this study upon a normal subject W. A. In Figure 6 are given the results of this experiment in which ACTH was given during the course of an isotope study. The rise in urinary uric acid excretion as well as the fall in serum uric acid is in every way comparable with that previously noted in the gouty subject. The absence of any change in the rate of decline of the isotope values following the administration of ACTH in this subject is clear evidence that no great increase in the rate of uric acid production had occurred. Such an increase might have been masked by the large size of the pool in experiment A. L.-2, but in the present experiment, where the pool size was quite small (Table IV) an increase in uric acid production sufficient to account for the uric acid diuresis should have been obvious. These results therefore strongly support the view that ACTH operates predominantly at a renal level and they conform with the views and findings of others (5-8) as to the mode of action of ACTH and corticoids upon uric acid and explain in part the mechanism of ACTH in the treatment of gout (9-12).

In the course of the third experiment, subject A. L. was given $1.2 \mathrm{mg}$. of colchicine every six hours for two successive days without developing signs of toxicity. No significant change in daily urinary excretion of uric acid or in its concentration in serum was detected (Figure 5) nor did any change in the slope of the isotope data occur.
TABLE V

Concentration of $N^{15}$ in urinary ammonia and urea samples*

\begin{tabular}{c|l|c|c|c}
\hline \hline Subject & Day & Ammonia & Urea & Uric acid \\
\cline { 3 - 5 } & & atom \% & atom \% & atom \% \\
A. L. (1) & 1.0 & 0.001 & 0.008 & 0.082 \\
A. L. (2) & 1.0 & 0.014 & 0.020 & 0.201 \\
A. L. (3) & 1.5 & 0.018 & 0.041 & 2.450 \\
& 4.0 & & 0.007 & 1.103 \\
W. A. & 0.12 & 0.009 & 0.023 & 5.218 \\
& 4.5 & 0 & 0.024 & 0.263 \\
\hline
\end{tabular}

* Urinary ammonia and urea have been isolated from certain urine samples and their isotope abundances compared with those of the simultaneously excreted uric acid.

Whereas Bishop and associates (13) have reported a contracture of the miscible pool of uric acid in response to colchicine in two out of three gouty patients, it should be noted that the subjects in which this effect was described had received no previous medication.

When uric acid labeled with $\mathrm{N}^{15}$ was previously injected, small though significant concentrations of $\mathrm{N}^{15}$ were found in certain samples of urinary urea and ammonia (1). In the present series we have again noted the appearance of $\mathrm{N}^{15}$ in urea and ammonia following the injection of uric acid labeled with $\mathrm{N}^{15}$ (Table V). This is taken to mean that to a limited extent uric acid is catabolized in man. The finding of Geren and colleagues (2) that oral administration of similarly labeled uric acid resulted in the appearance of an abundance of isotope in urea and ammonia suggests that the intestinal flora rather than the tissues of the host proper may be responsible for this degradation of uric acid.

\section{DISCUSSION}

The wide differences in the quantity of uric acid in the "miscible pool" observed when normal and gouty subjects are contrasted and when the same gouty subject is observed prior and subsequent to

TABLE IV

Injection of isotopic uric acid*

\begin{tabular}{|c|c|c|c|c|c|c|c|c|c|}
\hline Subject & $\begin{array}{l}a=\text { dose } \\
\text { injected }\end{array}$ & $I_{i}=$ injected & $\begin{array}{c}\mathrm{I}_{0}=\text { antiln of } \\
\text { intercept }\end{array}$ & $\underset{\text { pool }}{A=}$ miscible & $\mathbf{K}=$-slope & $\begin{array}{c}\mathrm{KA}= \\
\text { turnover }\end{array}$ & $\begin{array}{c}\mathrm{C}=\text { body } \\
\text { weight }\end{array}$ & $\begin{array}{c}\mathrm{A} / 0.7 \mathrm{C}=\text { mean } \\
\text { conc. in body } \\
\text { water }\end{array}$ & $\begin{array}{c}\text { Mean serum } \\
\text { level }\end{array}$ \\
\hline W. A. & $\begin{array}{l}m g . \\
200\end{array}$ & $\begin{array}{l}\text { at. } \% \\
30.4\end{array}$ & $\begin{array}{l}\text { at. } \% \\
5.70\end{array}$ & $\begin{array}{l}m g . \\
866\end{array}$ & $\begin{array}{l}d a y^{-1} \\
0.592\end{array}$ & $\begin{array}{c}m g . / d a y \\
513\end{array}$ & $\begin{array}{l}k g . \\
71\end{array}$ & $\begin{array}{c}m g . \% \\
1.7\end{array}$ & $\begin{array}{c}m g . \% \\
4.2 \pm .5\end{array}$ \\
\hline
\end{tabular}

* Isotopic uric acid has been injected into a normal man, and during the succeeding period the isotope concentration of his urinary uric acid was followed. ACTH was administered for two days during this period (Cf. Figure 6). 
TABLE VI

Quantities of rapidly miscible uric acid in fuid compartments of normal men*

\begin{tabular}{l|c|c|c|c}
\hline \hline Subject & $\begin{array}{c}\text { A } \\
\text { In total } \\
\text { pool }\end{array}$ & $\begin{array}{c}\mathrm{D} \\
\text { In plasma } \\
\text { water }\end{array}$ & $\begin{array}{c}\mathrm{A}-\mathrm{D}=\mathrm{E} \\
\text { In non- } \\
\text { plasma water }\end{array}$ & Ratio E/D \\
\hline & $\begin{array}{c}m g . \\
m g .\end{array}$ & $\begin{array}{c}m g . \\
1117\end{array}$ & 5.0 \\
D. C. & 1341 & 224 & 977 & 5.0 \\
R. B. & 1173 & 196 & 974 & 5.7 \\
G. W. & 1145 & 171 & 714 & 4.7 \\
W. A. & 866 & 152 & 946 & 5.1 \\
\hline Mean & 1131 & 186 & 946 \\
\hline
\end{tabular}

* The quantity of uric acid in the misciblelpool has been taken from the isotope data; the quantity in the plasma has been calculated from the mean concentration in serum and an estimate of quantity of plasma $(0.051 \times$ body weight). The difference between these two values is the miscible uric acid dissolved in non-plasma water.

treatment with uricosuric drugs demands that an attempt be made to determine the boundaries as well as the compartments of this miscible pool. Some steps in this direction can be made if it be provisionally assumed that the distribution of $d i s$ solved free uric acid between plasma water and remaining body water is determined by the relative sizes of these reservoirs, by membrane distribution effects and by nothing else. Assuming that these quantities are not markedly influenced by the presence of a gouty diathesis, it follows that the ratio of this distribution would be uniform in all our subjects. In the normal subjects this distribution may be computed (Table VI). The quantity of uric acid dissolved in plasma has been calculated from the average serum concentration, in each case, and from an estimate of plasma quantity $(0.051 \times$ body weight $)$. As there is no indication of uric acid occurring in the normal subject in any condition other than in solution, the difference between the total pool uric acid and the plasma uric acid has been taken to represent the uric acid in solution in non-plasma body water. The ratio of these last two numbers indicates that there is approximately five times as much uric acid in solution outside of plasma as there is plasma uric acid (Table VI). Included in this table are calculations from the three normal subjects previously reported (1), as well as normal subject W. A. described in the present paper.

If this same ratio is now assumed to obtain in the gouty patients, it is clear (Table VII) that the two compartments just considered fall far short of accounting for all of the uric acid shown to be present in the miscible pools of these subjects. That uric acid which is neither in solution in the plasma water nor in solution in non-plasma body water we take to represent urates present in the solid phase yet in mobile equilibrium with uric acid of the pool. It will be seen that it is this fraction which is the major variable, increasing with lack of treatment (A. L.-1 $\rightarrow$ A. L.-2) and dropping virtually to zero in response to therapy (A. L. $-2 \rightarrow$ A. L.-3). This reconstruction of the response to salicylate therapy is in accord with the extremely low isotope concentrations found in the tophus uric acid (Table III), in view of the fact that the tophus was excised during the third experiment, when, from the figures in Table VII it would appear that no solid phase urate is included in the miscible pool.

It must not be supposed, from the foregoing, that the writers contend that all the urate in the solid phase in patients with tophaceous gout is necessarily included in the "miscible pool." In subject A. L. this was clearly not the case, abundant tophi remaining after the course of salicylate treatment, at a time when the entire miscible pool appears to have been uric acid in solution.

One may picture that the outer layers of a tophus, comprising recently precipitated urates which are still in contact with body fluids are susceptible of rapid resolution and are included in the miscible pool, while the deeper layers, the chalky deposits of older vintage (cf. Figure 2), no longer in contact with body water, are incapable of resolution and are excluded from the miscible pool.

TABLE VII

The distribution of rapidly miscible uric acid in gouty patients*

\begin{tabular}{|c|c|c|c|c|}
\hline Subject & $\begin{array}{c}\text { A } \\
\text { In total } \\
\text { pool }\end{array}$ & $\begin{array}{c}\text { D } \\
\text { In plasma } \\
\text { water }\end{array}$ & $\begin{array}{c}\mathrm{E}=5.1 \mathrm{D} \\
\text { In non- } \\
\text { plasma } \\
\text { water }\end{array}$ & $\begin{array}{c}A-(D+E) \\
\text { In solid } \\
\text { phase }\end{array}$ \\
\hline $\begin{array}{l}\text { B. S. } \\
\text { A. L. (1) } \\
\text { A. L. (2) } \\
\text { A. L. (3) }\end{array}$ & $\begin{array}{c}\text { mg. } \\
4,742 \\
18,450 \\
31,019 \\
2,081\end{array}$ & $\begin{array}{l}m g . \\
261 \\
352 \\
371 \\
382\end{array}$ & $\begin{array}{c}m g . \\
1,331 \\
1,795 \\
1,892 \\
1,948\end{array}$ & $\begin{array}{c}m g . \\
3,150 \\
16,303 \\
28,756 \\
(-249)\end{array}$ \\
\hline
\end{tabular}

* The figures in columns $A$ and $D$ were arrived at as in Table VI. The uric acid dissolved in non-plasma water was determined by multiplying the quantity of plasma uric acid by the factor 5.1. The surplus miscible uric acid not contained in either of these two compartments has been assigned to the solid phase. 
The present findings are in accord with such a view.

The role of salicylates as prophylactic agents in the control of gout may be inferred from the foregoing discussion. They may fail to prevent the appearance of acute gouty arthritis and indeed Gutman (14) has observed the occurrence of such acute attacks during a course of treatment with salicylates which was effectively increasing uric acid excretion. The continuous administration of salicylates may however be expected to inhibit the growth of tophaceous desposits.

\section{SUMMARY}

The magnitude of the "miscible pool" of uric acid in a patient suffering from severe chronic tophaceous gout has been determined by measurement of the dilution of isotope which occurred when uric acid labeled with $\mathrm{N}^{15}$ was injected intravenously. This pool, which increased to a value of about $31 \mathrm{gm}$., or about 30 times normal, fell to a value of about $2 \mathrm{gm}$., or approximately twice normal when the uricosuric doses of acetylsalicylic acid were given.

The effect of ACTH upon uric acid metabolism has been studied in both gouty and the normal male subjects. The resultant uricosuria appears to arise exclusively from an increased renal clearance of uric acid. Colchicine had no demonstrable effect upon the quantities measured.

It has proved feasible to divide miscible uric acid into three compartments : 1) In solution in plasma water ; 2) In solution in non-plasma body water ; 3) In the solid phase. It is predominantly the uric acid in the last of these compartments that is subject to wide excursions in response to therapy.

\section{ACKNOWLEDGMENTS}

The authors wish to express their indebtedness to Mrs. Eleanor Schroeder and Mr. Frank J. Rennie for assistance in conducting the isotope analyses. They are also much indebted to Mr. Angelo Lippi who acted voluntarily as the chief subject in these investigations. The authors also gratefully acknowledge the constant interest and advice of Dr. George W. Thorn.

\section{BIBLIOGRAPHY}

1. Benedict, J. D., Forsham, P. H., and Stetten, DeWitt, Jr., The metabolism of uric acid in the normal and gouty human studied with the aid of isotopic uric acid. J. Biol. Chem., 1949, 181, 183.

2. Geren, W., Bendich, A., Bodansky, O., and Brown, G. B., The fate of uric acid in man. J. Biol. Chem., 1950, 183, 21.

3. Benedict, J. D., Forsham, P. H., Roche, M., Soloway, S., and Stetten, DeWitt, Jr., Pool of miscible uric acid in the gouty human. Federation Proc., 1950, 9, 149.

4. Forsham, P. H., Thorn, G. W., Prunty, F. T. G., and Hills, A. G., Clinical studies with pituitary adrenocorticotropin. J. Clin. Endocrinol., 1948, 8, 15.

5. Forsham, P. H., Thorn, G. W., Bergner, G. E., and Emerson, K., Jr., Metabolic changes induced by synthetic 11-dehydrocorticosterone acetate. Am. J. Med., 1946, 1, 105.

6. Thorn, G. W., Forsham, P. H., Bennett, L. L., Roche, M., Reiss, R. S., Slessor, A., Flink, E. B., and Somerville, W., Clinical and metabolic changes in Addison's disease following the administration of Compound E Acetate (11-dehydro-17- hydroxycorticosterone acetate). Tr. A. Am. Physicians, 1949, 62, 233.

7. Hellman, L., Weston, R. E., Escher, D. W., and Leiter, L., The effect of adrenocorticotropin on renal hemodynamics and uric acid clearance. Federation Proc., 1948, 7, 52.

8. Friedman, M., Bernstein, D., and Byers, S. O., Role of the adrenal cortex in the excretion of purines. Federation Proc., 1949, 8, 52.

9. Hellman, L., Production of acute gouty arthritis by adrenocorticotropin. Science, 1949, 109, 280.

10. Robinson, W. D., Conn, J. W., Block, W. D., and Louis, L. H., Role of the adrenal cortex in urate metabolism and in gout. J. Lab. \& Clin. Med., 1948, 33, 1473.

11. Thorn, G. W., Bayles, T. B., Massell, B. F., Forsham, P. H., Hill, S. R., Jr., Smith, S., III, and Warren, J. E., Studies on the relation of pituitary adrenal function to rheumatic disease. New England J. Med., 1949, 241, 529.

12. Wolfson, W. Q., Cohn, C., and Levine, R., Rapid treatment of acute gouty arthritis by concurrent administration of pituitary adrenocorticotropic hormone (ACTH) and colchicine. J. Lab. \& Clin. Med. (Proc. Central Soc. Clin. Research) (in press).

13. Bishop, C., Garner, W., and Talbott, J. H., Effect of colchicine and cortisone on uric acid metabolism in gout. Federation Proc., 1950, 9, 151.

14. Gutman, A. B., Personal communication. 